Jurnal Interpretasi Hukum | ISSN: 2746-5047

Vol. 2, No. 3-Desember 2021, Hal. 673-677| Tersedia online di

https://www.ejournal.warmadewa.ac.id/index.php/juinhum

DOI: https://doi.org/10.22225/juinhum.2.3.4195.673-677

\title{
PERLINDUNGAN HUKUM KORBAN PENIPUAN UNDIAN BERHADIAH MENURUT UNDANG-UNDANG NOMOR 11 TAHUN 2008 TENTANG INFORMASI DAN TRANSAKSI ELEKTRONIK
}

\author{
Kadek Yogi Pratama Putra, Anak Agung Sagung Laksmi Dewi, Luh Putu Suryani \\ Fakultas Hukum Universitas Warmadewa, Denpasar-Bali,Indonesia \\ yogipratama0922@gmail.com, laksmidewi29@gmail.com, putusuryani099@gmail.com
}

\begin{abstract}
Abstrak
Perkembangan zaman selalu diikuti dengan perkembangan teknologi, teknologi digital telah membawa pengaruh besar bagi kehidupan manusia. Salah satu contoh yaitu teknologi informasi dan komunikasi. Beraneka jenis telepon seluler dengan kecanggihan yang dimiliki telah merubah cara manusia dalam bertukar informasi dan berkomunikasi. Berbagai fitur tersedia di dalam telepon seluler salah satunya fitur layanan pesan singkat atau yang biasa dikenal dengan SMS. Pada awalnya fitur ini digunakan untuk memudahkan manusia dalam mengirim dan menerima pesan singkat. Seiring waktu fitur atau layanan pesan singkat tersebut dimanfaatkan oleh para pelaku kejahatan demi kepentingan pribadi. Kejahatan dalam dunia digital disebut dengan cybercrime. Oleh karena itu, adapun tujuan dalam penelitian ini yaitu untuk mengkaji pengaturan hukum korban penipuan undian berhadiah melalui layanan pesan singkat dan mengungkapkan bentuk perlindungan hukum bagi korban penipuan melalui layanan pesan singkat. Penelitian ini didesain dengan penelitian hukum normatif dengan menggunakan pendekatan Undang-undang dan konseptual. Sumber data yang digunakan adalah data hukum primer dan sekunder yang dikumpulkan menggunakan metode studi kepustakaan. Setelah data penelitian terkumpul tahap akhir yaitu mengolah dan menganalisis data tersebut secara deskriptif kualitatif. Hasil penelitian mengungkapkan bahwa kejahatan yang dilakukan oleh para pelaku merupakan tindak pidana penipuan yang mana telah diatur di dalam pasal 378 KUHP dan juga telah diakomodir di dalam Undang-undang ITE yang diatur dalam pasal 28 ayat (1). Selanjutnya korban mempunyai perlindungan hukum yang diatur dalam Undang-undang ITE.
\end{abstract}

Kata Kunci: Perlindungan Hukum, Penipuan, Undian Berhadiah

\begin{abstract}
The development of the times is always followed by technological developments, digital technology has broug ht a major influence on human life. One example is information and communication technology. Various types of cell phones with the sophistication they have have changed the way humans exchange information and communicate. Various features are available in cellular phones, one of which is the short message service feature or commonly known as SMS. Initially this feature was used to make it easier for humans to send and receive short messages. Over time the feature or short message service is used by criminals for personal gain. Crime in the digital world is called cybercrime. Therefore, the purposes of this study are to examine the legal arrangements for victims of sweepstakes fraud through short message services and reveal forms of legal protection for victims of fraud through short message services. This research is designed with normative legal research using a legal and conceptual approach. Sources of data used are primary and secondary legal data collected using the literature study method. After the research data is collected, the final stage is processing and analyzing the data in a qualitative descriptive manner. The results of the study reveal that the crimes committed by the perpetrators are criminal acts of fraud which have been regulated in article 378 of the Criminal Code and have also been accommodated in the ITE Law which is regulated in article 28 paragraph (1). Furthermore, the victim has legal protection as regulated in the ITE Law.
\end{abstract}

Keywords: Legal Protection, Fraud, Lucky Draw

\section{PENDAHULUAN}

Teknologi digital telah membawa pengaruh besar bagi kehidupan manusia diberbagai bidang kehidupan seperti ekonomi, pendidikan dan politik. Salah satu contoh yaitu teknologi informasi dan komunikasi. Ada beberapa jenis telepon seluler dengan kecanggihan yang dimiliki telah merubah cara manusia dalam bertukar informasi dan berkomunikasi. Berbagai fitur tersedia di dalam telepon seluler salah satunya fitur layanan pesan singkat atau yang biasa dikenal dengan SMS. Pada awalnya fitur ini 
digunakan untuk memudahkan manusia dalam mengirim dan menerima pesan singkat. Seiring waktu fitur atau layanan pesan singkat tersebut dimanfaatkan oleh para pelaku kejahatan. Kejahatan dalam dunia digital disebut dengan cybercrime (Sumarwani, 2019). Pada awalnya sebelum era digital seperti saat ini, komunikasi yang dilakukan oleh seseorang masih terbilang tradisional. Dengan perkembangan teknologi yang semakin canggih pada saat ini, manusia tidak lagi harus bertemu langsung ataupun mengirim surat untuk menyampaikan dan menerima informasi (Fitria \& Febrianti, 2020).

Kecanggihan teknologi pada era digital saat ini membawa perubahan bagi kehidupan manusia untuk memudahkan cara berkomunikasi, tidak sedikit yang memanfaatkan teknologi digital untuk melakukan aksi kejahatan. Kejahatan yang pada awalnya harus dilakukan secara langsung terhadap korban, di zaman sekarang dapat dilakukan melalui telepon seluler dan komputer. Dalam dunia digital dikenal sebagai cybercrime. Kejahatan dalam dunia digital atau cyber crime merupakan kejahatan yang dilakukan sesorang dengan cara memanfaatkan teknologi komputer. Semakin pesat perkembangan teknologi dan kreativitas operator dan penyedia layanan teknologi informasi, layanan pesan singkat yang pada awalnya hanya ditujukan untuk mengirim pesan, kini telah berkembang dan lebih variatif seperti mobile banking, ticketing dan lain sebagainya (Parsaorantua et al., 2017). Pada prinsipnya komunikasi merupakan sebuah proses untuk menyampaikan pesan dari suatu tempat ke tempat yang lain. Tingginya kebutuhan manusia akan teknologi informasi juga membuat tingkat kejahatan dalam dunia digital terus berkembang terutama bagi mereka yang ingin mencari keuntungan pribadi dengan cara menyalahgunakan beberapa penggunaan teknologi.

Kejahatan yang biasa dilakukan dalam dunia digital adalah penipuan. Berbagai modus operandi dapat dilakukan oleh para pelaku kejahatan untuk melancarkan aksinya dalam menipu korban. Salah satu contoh yang sering terjadi yaitu penipuan melalui pesan singkat dengan modus undian berhadiah. Berbagai cara dilakukan pelaku untuk meyakinkan korbannya bahwa hal tersebut benar. Jika kita tidak teliti dan waspada akan hal itu maka dapat dipastikan kita akan menjadi korban dan mengalami kerugian yang tidak sedikit. Penipuan itu sendiri dapat diartikan sebagai suatu perbuatan atau tindakan yang dilakukan oleh seseorang dengan berbagai rangkaian kebohongan untuk tujuan menguntukan si penipu tersebut dimana kebohongan itu merupakan suatu rangkaian cerita yang digunakan para pelaku yang seolah-olah merupakan suatu kebenaran (Sugandhi, 2007).

Penipuan melalui media elektronik semakin marak dilakukan dan tentunya telah merugikan banyak korban. Salah satu contoh penipuan yang dilakukan melalui layanan pesan singkat dimana para pelaku memanfaatkan sarana tersebut untuk melancarkan aksinya dalam menipu korbannya. Berbagai cara dilakukan penipu seperti mengirim pesan dengan nomor acak kepada korban-korbannya terkait dengan kasus penipuan undian berhadiah. Penerima SMS seperti itu jika tidak waspada dan teliti sudah pasti akan menjadi korban dengan potensi kerugian yang tidak sedikit.

Penelitian terdahulu telah melakukan penelitian yang punya relevansi dengan penelitian, namun sampai saat ini kasus penipuan melalui media online. Aksi kejahatan dengan penyalahgunaan teknologi digital sering terjadi dan menimbulkan keresahan di masyarakat, oleh sebab itu pemerintah harus memberikan aturan dalam kebebasan berbagi informasi lewat sosial media (Wahid \& Labib, 2005). Penelitian lain mengungkapkan bahwa para pelaku yang melakukan aksi kejahatan dalam dunia digital sulit untuk dilacak keberadaanya, karena dengan keahlian yang dimiliki mereka dapat merubah alamat IP yang digunakan untuk menghilangkan jejak (Kamasa, 2014). Untuk itu peran aparat penegak hukum khususnya dalam menanggulangi kejahatan cyber perlu lebih memperdalam keahlian dalam dunia digital untuk mempermudah proses penyelidikan terhadap para pelaku kejahatan tersebut (Sumarwani, 2019). Berdasarkan fenomena yang ditemukan dari beberapa peneliti terdahulu, maka penelitian ini sebagai lanjutan penelitian terdahulu untuk mengkaji ulang pengaturan hukum korban penipuan undian berhadiah melalui fitur pesan singkat dan mengungkapkan perlindungan hukum atas korban penipuan undian berhadiah melalui fitur pesan singkat.

\section{METODE PENELITIAN}

Penelitian ini menggunakan metode penelitian hukum normatif atau kepustakaan. Penelitian hukum normatif dapat diartikan sebagai suatu proses atau langkah-langkah untuk dapat menemukan sebuah aturan hukum, prinsip maupun doktrin yang kemudian dapat digunakan untuk menjawab suatu permasalahan hukum yang terjadi (Marzuki \& Mahmud, 2005). Penelitian hukum normatif mengkaji 
permasalahan terkait dengan kasus penipuan melalui sarana layanan pesan singkat. Proses penelitian ini menerapkan metode pendekatan state approach dan conceptual approach, serta menggunakan teknik pengumpulan bahan hukum primer dan sekunder dengan menggunakan teknik kepustakaan yaitu menganalisis terhadap literatur-literatur terkait yang telah ada maupun jurnal ilmiah yang tentunya relevan terhadap permasalahan yang diteliti. Setelah data terkumpul maka dianalisis menggunakan metode kualitaif deskriptif (Sunggomo, 2016).

\section{HASIL DAN PEMBAHASAN}

\section{Pengaturan Tindak Pidana Penipuan Berbasis Elektronik dalam Undang-undang Informasi dan Transaksi Elektronik}

Semakin berkembangnya teknologi di era digital saat ini, perlu adanya langkah-langkah yang dilakukan pemerintah guna mencegah tindak kejahatan dalam dunia digital yang semakin merajalela. Indonesia pada saat ini telah memiliki payung hukum dalam aspek teknologi informasi dan komunikasi yaitu UU ITE. Undang-undang ini diterbitkan sebagai bentuk dukungan terhadap teknologi informasi dan komunikasi agar semakin berkembang serta pemanfaatannya dapat membuat perekonomian semakin maju demi mewujudkan kesejahteraan rakyat. UU ITE juga diterbitkan guna memberikan perlindungan kepada masyarakat dalam penggunaan teknologi dan informasi demi mencegah seseorang dalam penyalahgunaan serta dapat menciptakan rasa aman dalam berkomunikasi, bertransaksi, serta pemanfaatan lainnya (Mansur \& Gultom, 2005).

Berbicara mengenai tindak kejahatan khususnya penipuan pada prinsipnya penipuan yang dilakukan secara online dan konvensional adalah sama namun yang membedakan hanya metode yang dilakukannya. Jika penipuan secara konvensional dilakukan dengan cara langsung terhadap korbannya, dalam penipuan yang dilakukan secara online, penipu dapat memanfaatkan sarana telekomunikasi yaitu telepon seluler maupun komputer dalam melancarkan aksinya. Dalam hukum pidana delik yang digunakan dalam penipuan secara konvensional dapat juga diberlakukan sama dengan penipuan melalui media elektronik. Selain daripada KUHP yang mengatur tentang tindak pidana penipuan, Indonesia juga memiliki aturan hukum yang menyangkut tentang Teknologi Informasi yaitu diundangkan Undang-undang No. 11 Tahun 2008 tentang Informasi dan Transaksi Elektronik (ITE). Undang-undang ini tidak sebatas memuat ketentuan pidana terhadap kejahatan melalui sarana telekomunikasi saja melainkan juga mengakomodir tentang pengelolaan informasi dan transaksi elektronik. Dengan adanya payung hukum ini diharapkan dapat mengoptimalisasi pengembangan teknologi informasi di Indonesia (Chazawi, 2002).

Tindak pidana yang dilakukan melalui sarana telekomunikasi telah diatur dalam Undangundang ITE dan ditetapkan terkait perbuatan-perbuatan apa saja yang dapat masuk dalam ruang lingkup kejahatan melalui sarana telekomunikasi tersebut. Ketentuan mengenai unsur-unsur yang dapat dikategorikan sebagai tindak pidana antara lain:

1. Jika seseorang dengan secara sengaja dan tanpa hak mendistribusikan maupun membuat dapat diaksesnya informasi maupun dokumen dengan adanya muatan pelanggaran terhadap kesusilaan

2. Jika seseorang dengan secara sengaja dan tanpa hak mendistribusikan maupun membuat dapat diaksesnya informasi maupun dokumen dengan adanya muatan perjudian

3. Jika seseorang dengan secara sengaja dan tanpa hak mendistribusikan maupun membuat dapat diaksesnya informasi maupun dokumen dengan adanya muatan penghinaan ataupun pencemaran nama baik.

4. Jika seseorang dengan secara sengaja dan tanpa hak mendistribusikan maupun membuat dapat diaksesnya informasi maupun dokumen dengan adanya muatan pemerasan maupun pengancaman

Penegakan hukum pidana merupakan suatu tindakan sebgai wujud menciptakan keadilan dengan memberikan sanksi kepada seseorang yang melanggar ketentuan sesuai yang diatur dalam peraturan perundang-undangan serta mencapai kepastian hukum dan kemanfaatan sosial dalam setiap hubungan hukum (Marzuki, 2008). Hukum merupakan suatu kaidah-kaidah yang diatur untuk mengatur segala sesuatu untuk mewujudkan masyarakat yang adil dan tentram, tentunya dalam proses penegakan hukum itu sendiri perlu peran manusia dalam hal ini aparat penegak hukum. Perlu digaris bawahi bahwa para penegak hukum tidak hanya sebatas menegakan hukum itu sendiri melainkan juga dapat menjadi perwujudan terhadap nilai-nilai yang terkandung di dalamnya. 
Dalam hal kasus penipuan penipuan melalui sarana telekomunikasi atau media elektronik seperti penipuan undian berhadiah melalui layanan pesan singkat, terdapat proses ataupun mekanisme dalam penanganan kasus tersebut yaitu yang pertama penegak hukum dalam hal ini pihak kepolisian dapat melakukan penyelidikan terhadap kasus yang terjadi untuk dapat menetapkan siapa pelaku kejahatan tersebut dan dapat menetapkan seseorang sebagai tersangka berdasarkan bukti permulaan yang cukup, Tahap berikutnya yang dilakukan yaitu proses penyidikan terhadap tersangka. Dalam proses penyidikan terkait dengan kejahatan cyber perlu keahlian untuk membuktikan kejahatan yang dilakukan mengingat proses pembuktian kejahatan cyber terbilang cukup sulit. Penyidik harus mampu memahami dunia digital agar mempermudah proses penyidikan dilakukan. Setelah proses penyidikan selesai, penyidik dapat menyerahkan berkas perkara kepada penuntut umum beserta tersangka dan barang bukti.

\section{Perlindungan Hukum atas Korban Penipuan Undian Berhadiah dalam Undang-undang yang Berlaku}

Perlindungan hukum merupakan suatu tindakan maupun aturan sebagai wujud memberikan rasa aman bagi masyarakat dari berbagi ancaman maupun tindakan kejahatan. Perlindungan hukum juga dilakukan sebagai upaya untuk menciptakan rasa keadilan bagi seluruh rakyat. Hukum menjadi norma terpenting serta menjadi alat control dalam kehidupan masyarakat karena dapat memberikan sanksi nyata dan tegas bagi orang yang melanggarnya. Dalam kasus penipuan, hukum pidana menjadi dasar untuk memberikan sanksi kepada para pelaklu. Seperti contoh penipuan melalui media elektronik dengan modus mengirim SMS undian berhadiah, pelaku dapat dijerat dengan pasal 378 KUHP terkait dengan penipuan serta pasal 27 ayat 1 Undang-undang ITE.

Kasus tindak pidana penipuan melalui media elektronik ini juga harus memberikan perlindungan hak-hak korban kejahatan tersebut. Hak yang diberikan kepada korban jika mengacu pada KUHAP sangalah minim dibanding dengan hak yang diberikan kepada terdakwa. Dalam Undang-undang ITE, perlindungan yang diberikan yaitu berupa penyelesaian perkara sampai pemberian sanksi terhadap pelaku kejahatan tersebut. Akibat hukum merupakan segala bentuk konsekuensi terhadapat perbuatan yang dilakukan oleh subjek hukum baik orang maupun badan hukum yang disebabkan karena peristiwa atau kejadian tertentu yang mana dalam atruran hukum itu sendiri telah ditentukan mengenai apa yang harus serta boleh dan tidak untuk dilakukan (Halim, 1985).

Mengenai akibat hukum dari kasus penipuan melalui media elektronik kitab Undang-undang Hukum Pidana (KUHP) dan Undang-undang Informasi dan Transaksi Elektronik (UU ITE) sebagaimana peraturan perundang-undangan yang berlaku di indonesia terkait dalam tindak pidana ini, masing-masing mangaturnya dalam satu pasal. Pelaku dapat dijerat dengan pasal 378 KUHP dan Pasal 28 ayat 1 Undang-undang ITE. Terhadap kebijakan yang dapat diterapkan kepada pelaku sepenuhnya tergantung kepada penyidik untuk menentukan Pasal mana yang akan dikenakan terhadap pelaku, serta perlu ketelitian dari pihak penyidik yang menanganiya. Namun tidak menutup kemungkinan juga pihak penyidik dapat menggunakan kedua pasal tersebut secara bersamaan atau istilah yang biasa disebut pasal berlapis, apabila memang unsur-unsur dari kedua pasal tersebut terpenuhi.

\section{SIMPULAN DAN SARAN}

\section{Simpulan}

Berdasrkan analisis data, dapat disimpulkan bahwa kecanggihan teknologi pada era digital saat ini membawa perubahan bagi kehidupan manusia untuk memudahkan cara berkomunikasi, namun ada yang memanfaatkan teknologi digital untuk melakukan aksi kejahatan. Kejahatan yang pada awalnya harus dilakukan secara langsung terhadap korban, di zaman sekarang dapat dilakukan melalui telepon seluler dan komputer. Dalam dunia digital dikenal sebagai cybercrime. Kejahatan dalam dunia digital atau cyber crime merupakan kejahatan yang dilakukan sesorang dengan cara memanfaatkan teknologi komputer. Terkait dengan perlindungan hukum korban tindak pidana penipuan melalui pesan singkat, KUHAP memberikan perlindungan hukum terhadap korban berupa hak atas laporan, hak untuk melakukan kontrol terhadap penuntut umum, dan hak atas penggabungan penuntutan ganti kerugian antara perkara pidana dan perdata. Sedangkan undang-undang ITE memberikan perlindungan hukum 
berupa penyelesaian perkara dan pemberian sanksi pidana yang diberikan kepada tersangka atau terdakwa. Terkait dengan perlindungan terhadap korban, terdapat suatu Perundang-undangan yang ditujukan khusus untuk memberikan perlindungan kepada saksi dan korban, yaitu Undang-undang Republik Indonesia Nomor 31 Tahun 2014 Tentang Perlindungan Saksi dan Korban. Sedangkan akibat hukum yang diberikan kepada pelaku tindak pidana penipuan yaitu ancaman pidana yang dapat dikenakan terhadap pelaku adalah pidana penjaran paling lama 6 (enam) tahun atau denda paling banyak Rp. 1 miliar sebagai mana disebutkan dalam Pasal 45 ayat (2) Undang-undang ITE, perihal ketentuan pidana dari pasal 28 ayat (1) Undang-undang ITE.

\section{Saran}

Berkaitan simpulan penelitian di atas, adapun saran yang diberikan peneliti yaitu diharapkan kepada pemerintah agar lebih waspada dalam mencegah terhadap berbagai macam aksi kejahatan dalam dunia digital seperti penipuan yang menggunakan sarana telekomunikasi atau pesan singkat dan tentunya pemerintah harus memperketat sistem registrasi nomor telepon dengan sistem kependudukan yang dirancang dengan baik agar mempersulit terjadinya tindak kejahatan seperti penipuan melalui pesan singkat dengan modus undian berhadiah yang kerap terjadi dan telah memakan banyak korban. Bagi aparat penegak hukum, diharapkan agar dapat menindak tegas para pelaku-pelaku penipuan dengan modus apapun melalui sarana telekomunikasi tersebut sesuai dengan aturan hukum yang berlaku agar masyarakat tidak menjadi korban. Bagi masyarakat diharapkan lebih waspada dan berhati-hati dengan semakin banyaknya modus-modus penipuan melalui sarana telekomunikasi, masyarakat juga harus lebih teliti jika menerima pesan singkat dari orang yang tidak dikenal agar tidak menjadi korban penipuan dengan modus apapun.

\section{DAFTAR PUSTAKA}

Chazawi, A. (2002). Stelsel Pidana, Tindak Pidana, Teori-teori Pemidanaan\& Batas Berlakunya Hukum Pidana Bagian I. Raja Grafindo Persada: Jakarta.

Fitria, K., \& Febrianti, Y. (2020). Pemakaian dan Sikap Perilaku Body Shaming di Media Sosial (Sebuah Studi Etnografi Digital di instagram). Jurnal Media Dan Komunikasi, 3(1), 12-25.

Halim, R. (1985). Pengantar Ilmu Hukum dalam Tanya Jawab. Ghalia Indonesia: Jakarta.

Kamasa, F. (2014). Kejahatan Kerah Puth Kontraterorisme dan Perlindungan Hak Konstitusi Warga

Negara dalam Bidang Ekonomi. Jurnal Konstitusi, 11(4), 782-804.

Mansur, D. M. A., \& Gultom, E. (2005). Cyber Law-Aspek Hukum Teknologi Informasi. Bandung: Refika Aditama.

Marzuki, \& Mahmud, P. (2005). Penelitian Hukum. Jakarta. Kencana Prenada Media.

Marzuki, P. M. (2008). Pengantar Ilmu Hukum. Kencana Prenada: Jakarta.

Parsaorantua, P. H., Pasoreh, Y., \& Rondonuwu, S. A. (2017). Implementasi Teknologi Informasi dan Komunikasi. Jurnal Acta Diurna, 6(3), 1-14.

Sugandhi. (2007). Kitab Undang-undang Hukum Pidana. Bumi Aksara: Jakarta.

Sumarwani, H. S. (2019). Tinjauan Yuridis Pemidanaan Cybercrime dalam Perpektif Hukum Pidana Positif. Jurnal Pembaharuan Hukum, 1(3), 287-296.

Sunggomo, B. (2016). Metode Penelitian Hukum. Rajawali Pers: Jakarta.

Wahid, A., \& Labib, M. (2005). Kejahatan Mayantara (Cyber Crime),. Bandung. PT.Rafika Aditama. 